\title{
LEARNING STYLES AND THE CONCEPT OF INTELLIGENCE AS ONE OF THE APPROACHES TO TEACHING FOREIGN LANGUAGES
}

\author{
СТИЛІ НАВЧАННЯ ТА ПОНЯТТЯ ІНТЕЛЕКТУ \\ ЯК ОДИН ІЗ ПІДХОДІВ ДО НАВЧАННЯ ІНОЗЕМНИХ МОВ
}

The article is devoted to the searching of effective approaches and methods in foreign language preparatiton of students of technical engineering specialties of higher educational establishments, by means of searching and determining their individual psychological characteristics and their inclinations to different learning styles. The prevailing kinds of information perception: Visual Modality, Auditory Modality and Kinesthetic Modality have been analyzed. The research has been done among 100 students of the 4th year of studying at the Institute of Telecommunication Systems. The object of the research was to define students' preferable learning style. It has been considered that for effective planning the educational process and creating the bank of appropriate tasks, it should be taken into account the level of students' preferable kind of perception information, their background knowledge, individual intellectual capabilities and likings. The modern analyses of numerous researches have shown that there are different approaches to such phenomenon as intellection and its classification from the point of view of different scholars. The phenomena of intelligence and intellection have been defined as the key factors of students' cognitive processes while their educational practice. The importance of individual (differentiated) approach in the process of teaching has been pointed out for providing positive atmosphere in the educational environment and stimulating motivation of students, that will set them up for achieving professional competencies and it will also help them to find productive means for further self-studying, for finding new information or advancing already obtained skills. But individual approach can be applied only if the academic groups are divided into small sub-groups. In the case the division is impossible, the lesson is conducted in a form of a lecture. Nevertheless, teachers should use three learning styles simultaneously, to encompass all his students in the studying process.

Key words: learning style, memory, intelligence, intellection, individual approach, cognitive process, Visual Modality, Auditory Modality, Kinesthetic Modality.

Стаття присвячена пошуку дієвих підходів та методів іншомовної підготовки сту дентів технічних спеціальностей вищих навчальних закладів шляхом проведення дослідження, аналізу, визначення їхніх індивідуальних психологічних характеристик та схильності до різних стилів навчання. Проаналізовано різні переважаючі види сприйняття інформації: зоровий, слуховий та кінетичний. Проведено дослідження серед 100 студентів 4 курсу Інституту теле комунікаційних систем на предмет визначення переважаючого стилю навчання. В результаті проведеного дослідження зазначено, що для ефективного планування навчального процесу та створення банку завдань варто враховувати переважаючі види сприйняття інформації, а також рівень мовної підготовки та індивідуальні інтелектуальні можливості студентів, їхні психологічні особливості та уподобання. Аналіз сучасних наукових досліджень показав, що існують різні підходи до визначення таких понять, як мислення, інтелект та розумова діяльність, які є ключовими складниками когнітивних процесів студентів під час їх навчальної практики. Під час дослідження було вказано на важливість застосування індивідуального (дияеренчійованого) підходу в прочесі навчання, що може допомогти створити позитивну атмосфреру в навчальному середовищі та значно підвищити мотивацію студентів. Також перевага індивідуального підходу в тому, що він налаштовує студентів на досягнення позитивного результату, що значно полегшить їм отримання професійних умінь та допоможе знайти продуктивні засоби для самостійного подальшого навчання, знаходження нової інформації чи вдосконалення вже набутих профессійних навичок. Але індивідуальний підхід можли вий лише при поділі академічних груп на підгрупи; якщо поділ неможливий, то заняття проходять у вигляді лекцій, і тоді інорормація сприймається студентами переважно слуховим методом. Проте викладачам пропонується застосовувати всі навчальні стилі в робочому прочесі, щоби задіяти всіх студентів, незважаючи на їх переважаючий вид сприйняття інфрормації.

Ключові слова: стиль навчання, пам'ять, інтелект, розумова діяльність, індивідуальний підхід, когнітивний процес, зоровий вид, слуховий вид, кінетичний вид сприйняття інформації.
Problem statement. The globalization processes in all spheres of human life at the beginning of the XXI century has predetermined important social changes not only in the fields of economy, politics, culture and information technologies, but also in the sphere of national education for providing an uninterruptable development of the society. The sphere of education has been converting into one of the main aspects of information medium and due to this, it requires qualitative transformations either in the creation of effective system of higher education, or in the choice of methods and approaches to the process of studying. In order to reform the system of education in general, the State National program "Education" and "National Doctrine of Education Development of Ukraine in XXI century" have been developed. The state policy in this sphere has predetermined the urgency to introduce the crucial changes into the system of foreign language teaching as the necessary condition for providing international cooperation in all spheres of the national economy. To meet all these needs, in recent years the leading teaches, applied 
linguists and scientists created different authoring programs and alternative textbooks; implemented into the studying process the newest educational technologies and developed non-traditional classes, applying person-oriented, "student-centered approach" to achieve the implementation of the main nowadays' principle of methodology - communicative approach.

Analysis of recent research and publications. The questions of modality preference and creating appropriate teaching methods were studied and developed by different foreign scholars and applied linguists, such as: N. Fleming, D. Baume, F. Constantinidou, S. Baker, J.A. Jenkins, J.D. Bransford, B. Rourke, S.Ahmad, D. Collins, B. Hayman-Abello, S. Hayman-Abello, J.J. Franks, E. Warriner, D.T. Willingham, C.S. Dodson, A.P. Shimamura, R. Dunn, K. Dunn, K.J. Perrin, S.A. Griggs, J. Olson, M. Beasly, B.S. Gorman, M.A. Gernsbacher, T.J. Kampwirth, M. Bates, K.A. Kavale, S.R. Forness and others.

Regarding the phenomena of intelligence and intellection many scientists and psychologists have devoted their researches and scientific investigations. Among these scholars are the following: J.W.F. Piaget, Ch. Spearman, L.L. Thurstone, H.J. Eysenck, D. Wechsler, J.K. Vernon, J.P. Gilforth, R.B. Cattell, R.J. Sternberg, H. Gardener, E.P. Torrance and others.

The aim of the article is to explore and identify personal peculiarities and learning style of each student for effective lesson planning, selection and adaptation studying materials to their learning abilities, interests and needs.

Presenting main material. The Higher educational establishments prepare specialists who have a good command in one or two foreign languages either for academic communication (scientific conferences, symposia, round tables), or for fluent communication at the household level (private letters, dialogues, small talks, watching movies, reading fictions, etc). But to achieve all these educational goals successfully, teachers should take into account the psychological aspects of the process of studying, which are based on understanding the new material, memorizing it and reproduction of it, when it is necessary. Also teachers should consider the learning ability of their students, their cognitive and mental skills that play an important role in the process of getting knowledge. Many pupils at schools and later students at Higher educational establishments feel uneasy and disappointed if they do not possess required cognitive skills and abilities to cope successfully with the syllabus and their studying at the university turns out to be a constant struggle or a dead-end job. Nevertheless, cognitive skills, as the necessary requirement for effective mental action, can be improved, strengthened and even enhanced with the proper and correct training. So, in order to plan their lessons effectively, teachers should pay attention to individ- ual learning styles and psychological characteristics of every student and diversify the methods and techniques of teaching. This approach will help them to choose the appropriate tasks and exercises and adapt learning materials to each category of students, to their particular needs and abilities. The phenomenon of individualization in the process of teaching is a complex structural approach that can be fulfilled with the help of differentiation in learning, concerning interests of students, their psychological peculiarities, inclinations and needs. Teachers have to work with students applying a great number of instructional strategies or "conducting a lesson at varying levels of tasks, concerning the ability of each student" [6]. Such approach helps them to organize effective working situations and a supportive learning surrounding that helps student to dose into the atmosphere of professional environment. It usually helps students to speak at the lesson without being afraid of making mistakes; to discuss particular questions or to share their opinions with interlocutors. To achieve all these goals teachers must be able to define the content of studying materials, regarding students' professional interests and specialization needs, their level of language proficiency. The process of knowledge acquisition is difficult and complicated due to individual students' style and ability of receiving information. That is why teachers should work out the individual style for every particular student or at least a group of students that would help them to obtain new skills and abilities. There are three basic types of learning styles that are categorized according to students' preferable mode of learning: Visual Modality, Auditory Modality and Kinesthetic Modality, which are also known as VAK modals $[1 ; 2 ; 4]$. These kinds of modality in their turn can be subdivided into subgroups. For example, visual learners can obtain $80 \%$ of required learning material in a better way with the help of illustrations, graphs, posters, maps, diagrams. The main features of visual learning modality are the following:

- studying via visual apprehension;

- studying via notification or display;

- dissimilar dimensional disposition in the notes;

- applying pictures, graphs, images, etc.;

- using diverse colors and signs in the books.

Learners with visual modality are inclined to employ words connected with sights, such as: to see, to notice, to watch, to show, to view. If a lecturer at the university do not use visual aids at his lessons, his visual students soon get weary and lose concentration on the subject. To attract the attention of visual learners in getting information, a lecturer has to assume as many different pictures to accompany his presentation as possible. There is also another approach how to help visual learners: psychologists usually advise them to use a system of different signs and symbols to substitute the words with images in copybooks during the lecture, because it would be easier to recollect 
a symbol than a word. So, a teacher should include different kinds of board games for teaching grammar structures, new vocabulary, phrasal verbs, etc. At the same time the studying material will be memorized better with color coding the notes, which causes the visual stimulation of students.

The main features of Auditory Modality are the following:

- studying via listening;

- visiting classes, speaking clubs and discussion sessions;

- recording studying materials and listening to them at home;

- reading the texts loudly, trying to imitate the speaker

- repeating the new words and phrases.

Auditory learners tend to apply sound phrases like: listen to, hear, say, tell, speak, etc. They can recollect the oral content of a lesson in details with ease, because this type of learners catch the new material via listening. That is why, such kind of activities as speaking through monologues and dialogues is the main condition for their good learning. Auditory learners prefer studying via discussion stories, using proverbs and quotations, listening to audio and video recordings, singing songs and reciting poems; they also take part in story building games with great pleasure, which makes their studying process more interesting and effective.

The main features of Kinesthetic Modality are the following:

- studying via activities;

- involving in practical exercises;

- remembering better via differentiating syllabus.

This kind of learners can study foreign languages by using their physical senses: touching, feeling, keeping, holding and doing hand-on exercises. They do their assignment by trying it out and they like to experiment, never looking at the instruction of the task. This kind of students like moving around the classroom and taking part in different kinds of activities, such as role playing, case studying, team gaming, craft gaming, etc. They must be involved in different actions, that can provide them with successful learning. There can also be parted out the Tactile Modality learners, who usually prefer taking notes during the lecture, or while reading a book; in order to remember the material better they like drawing different signs or small pictures; and they do well with hands-on activities.

That is why to find the better ways of communicating knowledge to students, the research has been done at the Institute of Communication Systems among 100 students of the 4th year of studying to define their preferable learning style. The following results have been obtained: 58 students turned out to be the Auditory learners, 30 students out from them are the Visual learners, and the rest are the Kines- thetic learners. This research proves the general meaning that "our learning styles are changeable during different periods of our life: in grades from kindergarten to third, new information is presented kinesthetically, grades from 4 to 8 are visual presented; and from grade 9 to college and into the working surroundings the needed information is presented to us mostly through auditory means, such as lectures" [5].

To stimulate motivation for studying and create positive atmosphere at the lesson, teachers should take into consideration not only students' learning styles, but also their psychological peculiarities and their mental abilities to study.

From ancient times to nowadays many scholars and practitioners have been studying the phenomena of intelligence as a cognitive process that is characterized by the ability of a person to acquire knowledge and to find effective ways of solving the problems. The concept of intelligence is based on the process of modeling the non-random relationships of the surrounding world. According to cognitive approach, intelligence is considered to be a set of cognitive operations. But different scientists offer different interpretation of intelligence.

The Swiss Biologist and Child Psychologist Jean W. Piaget defined the intelligence as "assimilation to the extent that it incorporates all the given data of experience within its framework. The mental life is also an accommodation to the environment".[3] The representatives of factor-analytical approach (Ch. Spearman, L.L. Thurstone, H.J. Eysenck, D. Wechsler, J.K. Vernon) considered the intelligence to be a universal ability, based on a genetic capability of a neural system to process data with a particular speed and accuracy. The psycho-genetic testing had been done and its results showed, that the part of genetic factors, being calculated according to dispersion of the results of the performed intellectual tests is very big, and its indicator has the value from 0.5 to 0.8 of variance. Due to these results, the verbal intelligence is supposed to be the most genetically dependant.

The English psychologist Charles Spearman worked out the factor-analytical theory of intelligence. He distinguished a "general factor", in accordance of which the intelligence is a kind of a "mental energy" and its level defines the success of solving any kind of the tests. The general factor of intelligence is more important for performing the tasks on abstract relationships and less important for performing sensor tasks. Except the "general factor", there are also "group factors" of intelligence, responsible for mechanic, linguistic and mathematical competences; and also there are some "special factors", that are responsible only for separate intellectual tests.

The American psychologist J.P. Gilforth introduced the cubic structure model of intelligence in three dimensions: operations (cognition, memory, assessment, divergent and convergent productivity), content 
(visual material, symbolic, semantic and behavioral), results (elements, classes, relations, systems, types of conversions and drawn conclusions). Meanwhile the English psychologist Hans J. Eysenck in his theory of intelligence picked out such elements as speed of intellectual operations, persistence and addiction to checking mistakes on the base of severity of which the level of IQ is defined. But the British psychologist Raymond B. Cattell in his factor-analytical theory of intelligence defined two types of intelligence: "fluid" depending on heredity and which is important in the tasks, that require adaptation to new situations; and "crystallized" intelligence in which the previous experience is reflected in work and actions. Besides these general factors of intelligence, R.B. Cattell highlighted some other ones, predetermined by the work of analyzers, as, for example, the factor of visualization, and another factors connected with the speed of data processing, with the capacity of memory, and the way of long-term memory playback. Also he distinguished the factor-operations criteria of intelligence, that coincide with those ones, defined by Ch. Spearman. Nowadays, the American psychologist and psychometrician R.J. Sternberg defines three kinds of mental activities:

- Verbal intelligence, characterized by the wordhoard and erudition;

- The ability to solve the problems;

- Practical intelligence as the capability to achieve goals.

The American psychologist Howard Gardener offered the theory of multiple intelligences. He has identified seven components of intelligence: formal-linguistic, spacious, logical and mathematical, musical, motive, interpersonal, intrapersonal. He argues that these bits of intelligence are relatively distinct from each other and every person has a particular level of them. In different cultures the accent is made on the development or creation of different types of intelligence. Each of them is presented by vertically located levels: perception, memorization and learning. At the same time another American psychologist Ellis Paul Torrance proposed the model of intelligence, where he highlighted such elements as verbal understanding, special impressions, inductive reasoning, counting ability, memory perceptual speed and speech fluency. In the process of ontogenetic development of thinking, a human-being is going through the number of stages: clearly-effective, clearly-shaped and conceptual thinking ones.

Conclusions. Thus, to create students' positive motivation and ensure success in the process of knowledge acquisition, teachers should plan their lessons for a small group of students regarding their individual characteristics: memory, intelligence, intellection, mode of thinking, preferences and their learning styles. Similarly, information at the lecture with a great number of students should be presented using all three styles, which will ensure all participants to be involved in the process of studying without paying attention what their preferred style may be.

\section{REFERENCES:}

1. Fleming, N., Baume, D. (2006) Learning Styles Again: VARKing up the right tree! Educational Developments, SEDA Ltd, Issue 7.4, Nov. 2006. P. 4-7.

2. How to Teach English For Different Learning Styles. URL: http://www.teachingenglishgames.com/ Articles/Learning_styles.htm.

3. Intellectual'nye protsessy - Kratkoye vvedeniye v psychologiyu - Psychologichesky slovar'. URL: http://psi.webzone.ru/intro/intro10.htm.

4. Understanding Your Learning Style. Wilfrid Laurier University: Study Skills and Supplemental Instruction Center, 2008. URL: http://web.wlu.ca/learning_ resources/pdfs/Learning_Styles.pdf.

5. Visual, Auditory, and Kinesthetic Learning Styles (VAK). URL: nwlink.com/udonclark/hrd/styles/vakt.html/.

6. Weselby, C. (2014). What is Differentiated Instruction? Examples of How to Differentiate Instruction in the Classroom. URL: https://education.cu-portland.edu/ blog/classroom-resources/examples-of-differentiated-instruction/. 